SCORECARD

McDonald's
The fast-food giant has
vowed to convert all its

UK distribution trucks to run on biodiesel - created from its huge stock of cooking oil.

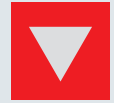

\section{Albert Gore} Al Gore's son has been caught speeding at 160 kilometres per hour in a Toyota Prius hybrid car. The offence doubles as a handy demonstration of low-carbon technology in the week of his Dad's Live Earth concerts...

\section{NUMBER CRUNCH}

3 crew members are currently on board the International Space Station.

6 will be the size of the crew by 2009.

\section{$\$ 19$ million is the amount} NASA has just spent on a new toilet system to keep them in the lap of luxury.

\section{SHOWBIZ NEWS}

The Horrible Girls from CERN Fans of particle-physics-based pop music rejoice: later this month, CERN - Europe's particlephysics laboratory near Geneva, Switzerland - will host its annual 'Hardronic Festival', featuring the long-awaited return of the band Les Horribles Cernettes. Alongside hits such as Mr Higgs and Every Proton of You, their photo is rumoured to be the first image ever posted on the Internet.

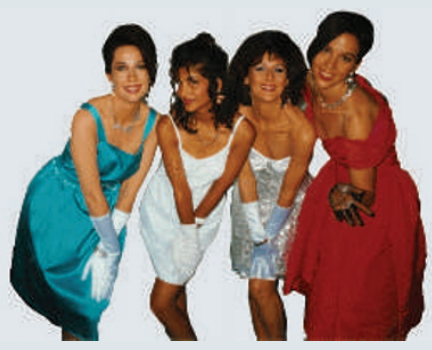

\section{ON THE RECORD}

\section{“Another female. It wasn't me."}

The response of Michigan state forensic scientist Ann ChamberlainGordon during her divorce trial, when asked what she had found when she used resources from her lab to analyse the DNA in her husband's underwear.

\title{
Austria's science institute gathers steam
}

Austria will, after all, get the élite graduatelevel institute it wants - even though plans seemed on the verge of collapse last year.

On 12 July, an 11-member scientific advisory board was expected to approve the focus for the planned Institute of Science and Technology. All research themes will be interdisciplinary, with focuses in the areas of biology, medicine and the physical sciences. Detailed research programmes will be defined by the institute's scientists, who are now being headhunted. The overall organizational structure follows the example of the Weizmann Institute of Science in Rehovot, Israel.

That's not surprising, as it is Haim Harari, a theoretical physicist and the former president of Weizmann, who has been driving plans for the institute. Originally spearheaded by Anton Zeilinger, head of physics at the University of Vienna, the project lost steam last year when Zeilinger left, complaining about the influence of local politics. Of particular concern was the decision to place the institute in the town of Gugging, 45 minutes from Vienna, at the site of a former psychiatric hospital.

Harari, who joined the project in late 2005, insisted that politicians should give the scientific community more control over the project. And although the institute will still be built at Gugging, fears have abated that the distance may make it less attractive as a workplace. Harari says that the campus "has fantastic potential - when you actually go there you can see that". And the institute may "come to life in a cloistered atmosphere," suggests physicist Olaf Kübler, chair of the scientific advisory board and former president of the Swiss Federal Institute of Technology - ETH Zurich.

Zeilinger has since returned to the scientific board and board of trustees, although he refuses to comment on the political decisions about the location.

With the decision to proceed now firmly in place, outside observers also see the need to gather leading scientists together. "Now it is necessary for the Institute of Science and Technology to reach a chain-reaction mass, so that it can get on with its work in the absence of closely neighbouring institutes," says Christoph Kratky, a molecular biologist from the University of Graz and head of the Austrian science fund FWF in Vienna.

The institute will not be part of the existing group of Austrian universities, which is largely seen as overly bureaucratic and not able to offer competitive packages to top scientists.

Germany and Italy, whose universities share the same historical system, have also toyed with the idea of building an elite graduate school from scratch. Germany, however, abandoned the idea in favour of topping up funding of existing universities that perform well, and the Italian Institute of Technology is floundering.

Government and industrial sources are supporting the Austrian project to the tune of 500 million euros over 10 years. If all goes to plan, the institute will eventually employ 500 people. With construction beginning in autumn, scientists who don't need complex equipment are expected to start work next year.

Carina Lenotti

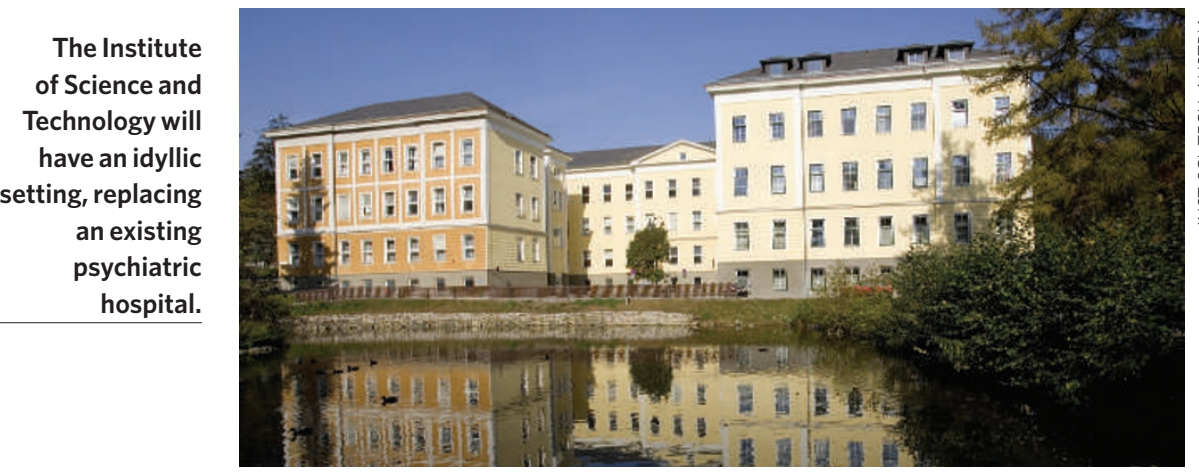

